DOI https://doi.org/10.36059/978-966-397-145-2/124-146

\title{
TRENDS AND PROSPECTS FOR TRANSFORMING CIVIL SOCIETY IN UKRAINE: SOCIO-CULTURAL ASPECT
}

\section{Romanenko S. S.}

\section{INTRODUCTION}

Ukraine entered the new millennium as the bearer of a young independent statehood, and right now, in the situation of extremely difficult external political challenges, internal political struggle, economic instability and social unrest, the Ukrainian society is at the stage of forming and determining the path of its development. The Ukrainian people made their choice, focusing on the European way of development, on a civil society. The events of Maidan and the aggression of the eastern neighbor just strengthened (at the cost of numerous human lives) the standpoint of progressive forces, Europeoriented citizens that the formation of a civil society is essential today.

Civil society is one of the phenomena of the modern world, an ideal to strive for. A true civil society cannot exist without the desire of the people themselves to make surrounding life better, to make a personal contribution to improve the social situation.

A developed civil society is an essential prerequisite for building a legal state and is its equal partner. Today, there are two opinions: "It us up to the residents of Ukraine to learn how they should solve their problems and change their lives for the better." And another opinion is "civil society should become an assistant of the state in solving our vital problems." So should the state be responsible for everything that is done in the society? And is there any civil society in Ukraine today?

The beginning of the 21 st century was marked by a global universal human crisis, which has become far more acute now, manifesting itself in a growing wave of social disintegration at the global 
level. For the modern Ukrainian society, this resulted in the aggravation of a number of problems, in particular, in the microsphere, such as loneliness, lack of a sense of life, conformism, amorality, social passivity, a sense of insecurity both at the individual and at the public and legal levels. All this is deeply rooted in the fundamental problem of the alienation of man from himself, the absence of man in man, the predominance of economic policy the purpose of which is to make an individual and his needs an object of manipulation by external economic and political forces. ${ }^{1}$

\section{Civil society: conception, formation and prospects}

The consequences of the totalitarian norms of social life, rooted during the Soviet period of history, the negation of amateur civil activity and other barriers are overcome by Ukraine in its own way, in its specific conditions. In addition to overcoming a number of mental factors that impede the formation of social relations, it is necessary to reproduce the main system-forming units of a civil society, the state of which depends to a large extent on the ability to reproduce or efficiently change its constitutive relations, their form and order. This ability of the system to be stable, sustainable, continuously carried out by the society's self-organization must be realized and applied in the active work of citizens. Thus, interest in mechanisms of social selforganization has the sense of a practical problem related to social management, social adaptation, and social forecasting.

In Ukraine, the topic of a civil society is popular and in demand for clarification. Does it already exist or does not, is it being formed at present, or is it advisable to build it, is a social project needed and what forces are responsible for its implementation, what is the state's place in this activity and how it, the state, interacts with a civil society in the

\footnotetext{
${ }^{1}$ Одинцова О. Н. Проблема отчуждения и гражданское общество. Философия и будущее ичивлизации: тезисы докладов и выступлений IV Российского философского конгресса. Т. 4. М.: Современные тетради, 2005. С. 453.
} 
modern Ukraine? Discussions on these issues continue. However, the sociological, economic and, finally, legal approaches prevail there, they mainly deal with the universal theoretical features of a civil society. Researchers no longer claim that we are building a civil society, that we have clearly presented its future appearance. We have to agree with the conclusion of the Austrian theorist who argued that for in fact we are able to bring about an ordering of the unknown only by causing it to order itself ${ }^{2}$.

To cause the self-ordering of a civil society in Ukraine is possible only by obtaining a scientifically proved idea of the mechanism of ordering and planning its activities to optimize this process.

Civil society is a phenomenon of the natural historical process. It consists in the fact that unification of citizens that actively influences various spheres of social life, in the course of history is formed, developed spontaneously, structured (in the form of institutions of society, associations, organizations or "corporations", as Hegel used to call them). This kind of formation has recently emerged and has come its way from the beginning of the 19th century to the present day.

The social and philosophical term civil society means neither all mankind, nor the population of a country and just the totality of its inhabitants, it expresses a special nature, a qualitative state of the social object in question.

As Karl Marx noted in "German Ideology", a civil society arose in the eighteenth century and denoted a certain state of the society, those changes in the material and spiritual aspects of people's lives, their communication which manifested themselves in the condition of capitalization of industrial manufacturing. Following that, another idea was formed - the idea of a reasonably organized society with a harmonious order based on a common sense, science and justice, with a

2 Фридмен, Милтон и Хайек, Фридрих. О свободе. Философия свободы. Вып. 2. М.: Социум, Три квадрата, 2003. 182 с. 
democratic legal state which guarantees the unity of public life, ensures progress and the highest goal - citizens' personal freedom, their mass political activity and their protection ${ }^{3}$. The bourgeois and democratic system introduced a new type of society in relation to the individual it declared freedom and self-identification of each person ${ }^{4}$.

The democratization of European power-holding regimes, the strengthening of the legal foundations of the society led to changes in the way people live, their communication with each other and within social institutions, in the forms of unification and organization of the latter. In place of faceless individuals with a prepersonal mythological and feudal "we-consciousness", with the consolidation of class rights and duties "tightly" determining a person's membership in the nobility, clergy, his inclusion in the peasant community, in the craft workshop, in the trade guild, the right of person's self-consciousness, the right to choose independently and individually, person's self-identification and self-realization were proclaimed. All this was enshrined in legal documents - bills, declarations, constitutions. The main sign of a democratic way of organizing a joint life of people was the legal fixation of "personal rights", officially legalized value of a person, regardless of his social status, ethnicity, gender, age, religion. As well as a person, civil society was a new European entity, it gave rise to a democratic form of the society existence 5 . Civil society, in turn, was reproduced by democracy itself, and showed the power of activating the masses in itself.

The masses, in the name of strengthening democratic rights and freedoms and legal autonomy of the individual, self-organize and form

3 Зеленко. Б. И. Гражданское общество. Глобалистика. Энииклопедия. М.: Радуга, 2003. С. 276-279.

${ }^{4}$ Каган М. С. Формирование личности как синергетический процесс. Синергетическая парадигма. М.: Прогресс-Традиция, 2003. С. 213-216.

5 Каган М. С. Формирование личности как синергетический процесс. Синергетическая парадигма. М.: Прогресс-Традиция, 2003. С. 213-216. 
free, initiatively arising associations, communities, institutionalized organizations that are independent of political power and are able to influence it.

Without going into the problems of defining a civil society from the point of view of various social sciences, we shall try and define it in the broadest sense. Thus, civil society is a certain type of social organization. In political science, this definition is specified as a stable system of horizontal connections, socio-political orientations and norms of social behavior within the framework of a democratic political system. Civil society has a complex structure, including economic, household and family-related, ethnic, religious, legal relations, as well as the relations between individuals as primary subjects of political life with the mediation of the state and so on.

As already noted, civil society is an integral attribute of a developed democracy, but its individual manifestations in some areas of public life can be observed in undemocratic states. In modern political science, the level of civil society's development has become a measure of the level of democracy in the state.

Civil society is a set of public institutions that are not directly included in the structure of the state and that allow citizens, their associations to realize their interests and initiatives. A modern mature civil society is a society of free self-organization. Professional, cultural and other communities which it consists of, are open to those who consciously seek to unite themselves based on common interests ${ }^{6}$. It is also necessary to single out one of the main features of a civil society the ability of the state's citizens to judge it and influence its actions, on the one hand, and the ability of the members of a community (society) to influence changes in social relations and social events ${ }^{7}$.

6 Марков С. А., Ярмак Ю. В. Вестник Российского философского общества. М.: СиДиПресс. 2007. Вып. № 1 (41). С. 98-102.

${ }^{7}$ Конев В. А. Каков наш путь к гражданскому обществу? Вестник Российского философского общества. М.: СиДиПресс, 2006. Вып. № 2 (38). С. 32-35. 
Since society is a complex system consisting of various communities, it can be divided in ideological, material, political, legal, cultural, ethnic, religious, social and other respects, and differ in mental and moral characteristics. Therefore, the question of the quality of the society itself which should precede the question of the quality of the state arises $^{8}$. According to the Western European tradition of civil society, this is the tradition of civil unification based on rights and law ${ }^{9}$. And if Western experts measure progress in the development of civilian structures by the number of non-governmental organizations that are emerging, in our country it is measured by how fully the state is immersed in this process, how many events of a supposedly civil nature were carried out with the participation of government officials and with the help of the authorities ${ }^{10}$.

How consistent is our citizens' understanding of life and relations in a mature civil society with the understanding of Europeans, where social relations within the framework of a civil society have considerable experience and are fixed as a tradition passed down from generation to generation. Any tradition is the transmission, translation of social experience, including social relations, and in this regard it is communication between generations as social groups. It is a constant renewal of the communication between generations that ensures the stability of the phenomena of social reality. Tradition is the main form in which the accumulation of social experience takes place, and provides objectivity as the external task of social realities.

8 Кравченко И. И. Государство и общество. Вопросы философии. 2007. Вып. № 7. С. 19-35.

${ }^{9}$ Конев В. А. Каков наш путь к гражданскому обществу? Вестник Российского философского общества. М.: СиДиПресс, 2006. Вып. № 2 (38). С. 32-35.

${ }^{10}$ Солонин Ю. Н. Практическая философия как предпосылка гражданского общества. Человек постсоветского пространства: сб. матер. конф. / под. ред. В. В. Парцвания. Вып. № 3. СПб.: Санкт-Петербургское философское общество, 2005. C. 419-435. 
Social communication is an integral part not only of historical development, but also the actual functioning of social reality, since social relations are the forms of social communication. At the level of the social system's self-maintenance in actual communication, the entire system of institutionalization of patterns and standards of activity is formed $^{11}$.

As history testifies, the processes of forming new relationships in the society are by no means transient, and require interaction of typically opposing parties - the society (people) and the state (government). So, one of the first documents of the medieval Europe, where legal relationships in the society are recorded, is considered the Magna Carta of 1215, which became the basis for the emergence and formation of the legal state and civil society in England for many centuries ${ }^{12}$. Over the course of two centuries, the Charter was confirmed 37 times, expanding from 39 articles to 63 , which indicates constant pressure on the part of the society towards the realization of their rights and freedoms. Thus, the Magna Carta of 1215 was of crucial importance in developing the ideas about human rights and proclaimed "free man" to be the subject of relations.

Compliance with the law gave impetus to the development of legal relations in England, as evidenced by later legal documents, such as the Petition for the Law of 1628, the Habéas Corpus Act of 1679, the Bill of Rights in 1689 and a number of others which also proves the development of a legal state ${ }^{13}$.

11 Мартишина Н. И. Взаимоконструирование реальности и человека Конструирование человека: сборник трудов Всероссийской научной конференции с международным участием: в 2т. Т.1 Ч.1. Томск: ТГПУ, 2008. С. 210-215.

12 Юдовская А. Я. Эволюция права в государствах Европы и Америки (XVII - XIX вв.). СПб.: Спец. лит., 1996. 164 с.

13 Козинець О. Г. Історія становлення інституту прав людини в Англії. Наукові дослідження - теорія та експеримент '2006: матер. другої міжнар. наук.практ. конф. Полтава: «ІнтерГрафіка», 2006. Т. 3. С. 26-29. 
Civil society appeared where property, law and rights were respected, the application and enforcement of which were rigorous ${ }^{14}$.

And although civil society as a phenomenon arose during the course of European bourgeois revolutions, that is, from "the bottom", today every state that has proclaimed itself as a democratic one, must a priori contribute to the development of civil society institutions from the top.

The idea of a civil society over the past decades expanded, deepened and was complemented by the idea of democracy based on political pluralism, a common competition and partnership of competing social groups; the idea of restricting state power by means of established legal norms, the idea of individual human freedom, and the expansion of democracy in social terms.

In virtually any type of society that we can distinguish based on its characteristics, such as the historical period, mentality, religion, economic development, political management system and others, processes of social organization take place, but in different time frames. A significant role is played by the historical period when the given civil formation manifests itself. It should be noted that at the present stage, all processes have accelerated, including the processes of reorganizing social relationships, due to the sharp acceleration, or even leap of industrial, computer, communication, information technologies, etc.

In the 21st century an attempt to introduce the concept of global civil society is being made. A number of Western theorists emphasize that in the context of globalization of all life spheres, there appeared a formation of a broad non-political community of people involved in solving generally significant problems of all mankind. Societal (following Parsons, the phenomena and processes related to the macro level, i.e. the level of society as a whole) communities with a close

14 Неретина С. С. Памятка о гражданском обществе. Философские науки. М.: Гуманитарий, 2008. № 7. С. 23-38. 
socio-political structure and common values advocate for the environment, peace, human rights protection, while crossing national borders, embracing global space, affirming growing global thinking. Global civil society tends to manifest itself as an initiative of social movements and civil associations. Free from the interference of political forces, global civil society will gradually get the opportunity to gain a foothold in the status of the main subject of the society's self$\operatorname{organization}^{15}$.

\section{The socio-cultural aspect of transforming Ukrainian civil society}

With regard to Ukraine, the starting points of a civil society in the modern sense can be traced in the developed system of trade unions back in the Soviet Union times. However, the level of a civil society is assessed not only by the quantitative indicators (the number of public and trade union organizations, their members, etc.) or by the presence of relevant laws, but primarily by the qualitative ones - by the effectiveness of the respective institutions and their real impact on improving the social climate of the society.

Significant stages in the history of the development of Ukrainian civil society include the dissident movement of the Soviet era, the Granite Revolution, the All-Ukrainian referendum on the declaration of independence of Ukraine, miners' strikes in the early and mid 90s, the Orange Revolution, the Revolution of Dignity, and the mass volunteer movement in support of the Ukrainian army. In addition to these peaks of civil activism, it is worth noting also the emergence and development of independent journalism, the formation and activity of numerous public organizations of various directions in various fields of society,

15 Резник. Ю. М. Глобальное гражданское сообщество. Глобалистика. Энцииклопедия. - М.: Радуга, 2003. С. 233. 
local access of the public through deliberative bodies to political decisions, and the construction of a multi-party system.

On the other hand, the effectiveness of a civil society depends on the political education of its citizens, which in turn should be promoted by a truly democratic state. In a country with an insufficient level of political culture and public awareness, on the one hand, political populism is always thriving, and on the other, there is a risk of establishing an ochlocratic governing regime in case there are a lot of democratic freedoms for an "ignorant" and "unprepared" crowd.

As far as the Ukrainian society is concerned, James Mace characterizes it as a "post-genocidal society", a society that has undergone so barbaric totalitarian repressive "treatment", moreover, over the course of life of more than one generation, that people who have gone through such merciless trials (definitely, it is not true about the whole society, but about its substantial, significant part, and it is really scary), consciously or unconsciously lose the basic values of human and national life: civil dignity, historical memory, love for freedom, economic and social initiative, the desire to be at least to some extent independent of the authorities, of the directives of the next leaders who "better than anyone" know what the country needs. Instead, both the Stalinist regime of bloody totalitarianism and the Brezhnev regime of "soft" totalitarianism systematically and thoughtfully cultivated, nurtured slavish proneness to compromise, conformism, unconsciousness, silent obedience, paternalism, hope in virtually everything for the good will and help of the state or authorities (though, publicly, from the tribune, for example, of the XXV Congress of the CPSU, another thing was stated: "Nothing elevates a person so much as an active life position does!" - which is a vivid illustration of the

16 Мейс Джеймс. Спадщина голодомору: Україна як постгеноцидне суспільство: газета. «День». №26. 2003. URL: http://www.day.kiev.ua/ru/arhiv/no2072015 
hypocrisy of the Soviet regime). And it is not surprising that the psychology of "not showing off" covered all new areas of the society; although it should be immediately emphasized that at all times there were people who strove to live the truth, proceeding from eternal moral and ethical values. But they were not enough to qualitatively change the life of Ukrainians.

And such a society met the proclamation of an independent Ukrainian state on August 24, 1991. As James Mace emphasized, "independence gained the Ukrainian USR" there was simply no other institutionalized Ukraine at that time; and it could not be, given what we talked about above. It was in such realities that we had to create (not renew, because that was the choice of the "elite") our sovereign state. What do we see now? There are two Ukraines: the Ukraine of the fearless Maidan of dignity, which is ready to give its life for freedom (and gives power, to put it mildly, to the dubious "Maidan Stage" - this is a tragedy!), and the Ukraine which cannot (even if it sincerely longs for this) get rid of the post-genocidal heritage, thereby depriving itself of a worthy human future ${ }^{18}$. That is why to withdraw Ukraine, once and for all, forever, from the "postgenocide" era (in terms of James Mace) is the only urgently needed reform program for the people and the state ${ }^{19}$.

This task is complicated by the fact that, firstly, history has given us an extremely rigid, extremely short period of time for its solution (otherwise we will be left back, hopelessly and forever). And, secondly, the Europe of democratic values, for the help of which we have all hoped so far, does not always understand the depth, drama and

17 Ibid.

18 Мейс Джеймс. Спадщина голодомору: Україна як постгеноцидне суспільство: газета. «День». №26. 2003. URL: http://www.day.kiev.ua/ru/arhiv/no2072015

19 Сюндюков И. Джеймс Мейс - о скрытом «измерении» геноцида: газета. «День». №207. 2015. URL: http://www.day.kiev.ua/ru/arhiv/no207-2015 
complexity of our problems (also burdened, among other things, by shameful corruption!), neither did it understand what was happening in Ukraine in 1932-1933 (with a few, unfortunately, exceptions: Gareth Jones, Lancelot Lawton, Malcolm Meggeridge). Did not it "just know" then? It is quite possible; however, later, when the world already learned about these horrors - what happened then? It didn't want to realize, didn't want to break "mental comfort" (although there were Robert Conquest, James Mays, Andre Glucksman)? But the fact is that both the genocide of 1932-1933 was a special, unique phenomenon in history (the extermination of the people not by force of arms, but by the terror of hunger), and a post-genocidal society is such a phenomenon that cannot be approved in light of any, even very "democratically" - oriented, standard approaches. A special "key" is needed here. And the adoption of a package of laws, even the best ones, cannot solve the problem.

The genocide of Ukrainians undermined the "health" of the nation. And its consequences have been "poisoning" the society up to nowadays $^{20}$.

In Ukraine, civil society is in its infancy since the majority of the population and people in power are not ready for changes. In connection with the young age of Ukraine as an independent state there are certain difficulties in perceiving the essence of a civil society. It turns out to be easier for a person to imagine himself in the context of state relations than in a system of civil interdependencies and social ties.

Relations in the modern Ukrainian society are formed by people brought up in completely different circumstances, in a different era. And although in comparison with the closed society of a totalitarian state we are now absolutely open, and instead of a rejected ideology, streams of various information, including possible social relations, have rushed into the formed vacuum; we are not able, for the most part, to reset the

${ }^{20}$ Ibid. 
stereotype of objectness, to remove the established tradition of being controlled and shown the way out from our consciousness.

In the 90s, when the Soviet system of governance collapsed, the legal system collapsed as well, Ukraine faced a situation when, with a legislative base, albeit inherited from a socialist past, those in power interpreted the law according to the principle of double standards. In such a situation, we can talk about the structural, social, political and other characteristics of the society, but not about a society of independent subjects.

In the absence of legal protection in the society, the mechanism of self-defense worked, it consisted in the accumulation of material resources, since the number of banknotes was the best defense. A society in which the rule of law is not based on law, but on the principle that he who pays the piper calls the tune, cannot produce the values of a civil society.

The paradigm shift process involves a rather long "frozen" period when the old is broken and the new is not there yet. The only common platform for human connectivity is money. This power system can be called coinocracy. During such a restructuring, thinking for one's constant renewal needs neither memory, nor personality, nor faith, providing themselves with those opportunities that are associated with monetarism. The way out through such a cataclysm is dangerous since it opens all the ways, including the old ones, where attempts are made to renew both memory, faith, and patriotism: these are authoritarian ways. With the loss of support in sociality along these paths one finds a desire and an opportunity (through financial capital, military force) to impose on society the decisions that it has already got rid of, but because of "tiredness", it is ready to accept them back $^{21}$. But in a situation where the money

21 Неретина С. С. Памятка о гражданском обществе. Философские науки. М.: Гуманитарий, 2008. № 7. С. 23-38. 
supply began to concentrate in the hands of a minority (a small handful of oligarchs), the conditions arose for the formation of a middle class - active people with money, but not sufficient enough to ensure full protection against lawlessness. We can say that the public vanguard began to form, which started to advance the idea of forming a civil society and constructing a legal state.

Apparently, it is worth noting that civil society is not the whole society, but it is its vanguard, perspective, developing part, capable of leading the rest of the society and replenishing itself from its composition. Civil society, according to Hobbes and his followers, is called upon to become the pillar of the state, in other words, that vanguard part of the society that can start partnership relationships with the country's leadership ${ }^{22}$.

In Ukraine, the formation of relationships inherent in a civil society manifested itself in the emergence of a mass of public entities: human rights organizations, civil disobedience associations (politicized and absolutely not), volunteer organizations, charitable foundations, environmental activists, professional associations, creative unions, fan clubs, and interest communities. In such associations, a person learns to be the subject of his activity, such associations can be perceived as micromodels of a civil society, where relationships are built on the principle of absolutely voluntary choice and participation, the opportunity is given to formulate and defend one's opinion, participate in shaping the direction of the community's activity, and many other opportunities of implementing subjectness.

The movement towards a civil society itself is "a gradual awakening of healthy needs, dignity, honesty, civil activism and responsibility among people". In other words, their transformation from the "right population" (according to M. Hrushevsky) into free,

22 Кравченко И. И. Государство и общество. Вопросы философии. 2007. Вып. № 7. С. 19-35. 
independent and socially active citizens who are able to control power and prevent it from turning to a hierarchical regime or autocracy $^{23}$.

In addition to the essential characteristic of the very ability of the society in the course of its self-organization to structure associations of individuals, it is legitimate to focus attention on social formations of a cultural and ethnic orientation. Such formations, caused by a community of interests or purposeful aspirations, were formed by the efforts of the participants themselves according to their voluntary choice. The time of their appearance coincided with the period of the revival of the "small peoples" of the Russian Empire and served as a manifestation of beliefs about the need to protect the traditions of the past, especially organizational traditions. The support of these traditions for the national revival of Ukrainians in the last decades of the nineteenth and early twentieth centuries in Russia, with its industrialization, modernization, politicization, expansion of education and the growth of social mobility, with the strengthening of Russification trends, has become cultural and ethnic communities Hromadas. The Hromadas' traditions, with their pronounced elements of community, corporate collectivism, permeate the entire prerevolutionary history of the Ukrainian national movement, which requires the presence of persistent, albeit inert, sometimes inactive structures based on personal connections, devotion to the idea, corporate ethics, which are a continuous thread connecting decades, generations, ideas, forms and methods of work. But at a certain moment they branch, evolve and, having fulfilled their mission, disappear.

23 Дулин П. Г. Гражданское общество и государственная власть в Украине. Украина в системе современных ичивилиаций и трансформации государства и гражданского общества. Одесса: «ВМВ», 2006. С. 118-120. 
Hromadas are clubs of the Ukrainian intelligent people that appeared in the middle of the 19th century and existed until the beginning of the 1900s. The term "hromada" was first used by the representatives of Polish democratic students in the title of the collection "Excerpts in Prose and Poetry by Joseph Prosper of Hromada" (Kyiv, 1858). The name "of Hromada" meant the collective pseudonym of the student group, united by common scientific and public interests and being part of the student commune (community) of Kyiv University, and which is more, its most advanced part.

Hromadas, in our opinion, are the most viable centers of the Ukrainian revival, which played a unique, perhaps not yet fully appreciated, role of the guardians of national traditions and, at the same time, generators of new ideas, the role of a "shelter" for those few Ukrainian intellectuals who did not want to finally dissolve in the "allRussian" anti-imperial liberation sea, the role of "connectors" in the "intervals" of the national revival, the role of educators and guardians of the young generation. Hromadas were out of certain estate, strata of the society, multinational, apolitical organizations, inspired by the idea of Ukrainian national revival. The Hromadas acted as the leading organizational form of the Ukrainian movement at the "cultural" ("organizational") stage.

The main stages of the evolution of Hromadas coincide with the general periodization of the Ukrainian national movement and the leading lines of the development of Ukrainian socio-political thought. National revival is a long process that includes three stages: 1) "academic" - "nostalgic" time for collecting heritage; 2) "cultural", or "organizational" - the transformation of the national language from the subject of study into an instrument of literary creation and translation, the establishment of a network of cultural organizations through which the national consciousness is introduced by the intelligent people, "pioneers of the national idea", deep into the ethnic mass; 3) "political" - the stage of mass national movements. In fact, there is an 
intersection and interweaving of all the three stages. The active force of this process is "wake-upers" and "activists" represented by hromadas, the object of influence is the people ${ }^{24}$.

The situation in the Odesa community of the $90 \mathrm{~s}$ of the $19^{\text {th }}$ century is a good illustration. Thus, L. A. Smolensky believed that "the very existence of hromada, even without any work, is of great importance, since it organizes, encourages people, does not allow to leave the idea of national revival," and any other idea. The statement of E. Kh. Chikalenko is also quite interesting: "We had dinner together, and any dividing of bread and drinking of wine in the collective brings them together and unites them. And this is extremely important, because when the whole Ukraine is covered with such hromadas, even inactive ones, the hour of organized collective coming out will arrive, then it will be easier for people to unite, since they will be already united" 25 .

In the presence of such intra-social relations, it can be said that the process of social communication will be filled with the corresponding tradition of social relations and social experience. The next generation, which is already taking effect, will not have to give birth to something new and unnatural, but to develop the already received tradition of social relations and go to a new level of relations between the society and the state. The world where social individuals live and work, and which they perceive as initially and objectively given, is actively constructed by people themselves in the course of their social activities, although this happens unconsciously for themselves ${ }^{26}$. A person creates social reality

${ }^{24}$ Пасько Я. Феномен соціальної держави в історичній традиції Філософська думка. 2007. № 2. С. 40-48.

25 Пасько Я. Феномен соціальної держави в історичній традиції Філософська думка. 2007. № 2. С. 40-48.

${ }^{26}$ Розин В. М. Особенности конструирования действительности и человека в философии и эзотерике. Конструирование человека: сб. трудов Всероссийской научной конференции с международным участием: в 2 т. Т. 1 Ч. 1. Томск: ТГПУ, 2008. C. 33-38. 
by investing in created objects - material and non-material - certain human meanings, a certain combination of senses; social reality creates a person, since the development of these meanings and senses forms the basis of his socialization ${ }^{27}$.

The problem is how to realize the society's aspiration towards civilized life in the necessary humanistic direction. In modern real life, one has to observe that it is difficult to reconstruct the course of the society's development by means of only centralized efforts, for the new appears spontaneously, in the form of separate fluctuations. If they are energetically nourished and not washed out in a constant interaction and mixing with the old, then the development of the entire system takes the right direction ${ }^{28}$. In relation to the modern society of Ukraine, this means the need for continuous monitoring of spontaneous social phenomena and targeted support for those processes that seem positive and rational in terms of the transformation of a civil society. The wisdom of politicians and the progressive nature of the society is to precisely determine the place and time of support for those new social phenomena that contribute to the realization of the ideas of humanism and the building of a civil society.

Initiative, non-formalized structures of the society do not yet form a dense social environment in Ukraine. The formation of a dense civil society environment can and should be promoted through the creation of favorable information, legal, economic and other prerequisites and conditions for the development of public structures, the protection and

27 Мартишина Н. И. Взаимоконструирование реальности и человека Конструирование человека: сборник трудов Всероссийской научной конференции с международным участием: в 2 т. Т. 1 Ч. 1. Томск: ТГПУ, 2008. С. 210-215.

28 Романенко С. С. Гуманизм как воплощение ценности человека. Наукові дослідження - теорія та експеримент '2006: матеріали другої міжнар. наук.практ. конф. Полтава: «ІнтерГрафіка», 2006. Т. 3. С. 159-162. 
realization of their legitimate interests, mutual dialogue, as well as a dialogue between them and the state ${ }^{29}$.

\section{CONCLUSIONS}

Can civil society be the goal that we strive for, in its autonomy from political life, from the state outer shell, as an independent and self-sufficient unit initial for all other functions and formations, a fundamentally primary structure in which the basic life process of a person and their interests are realized? It is quite necessary to orient the society, and first of all, its advanced part, the vanguard, which is formed by the middle class, towards the achievement of this goal, which is possible to achieve, although not in one's generation span.

The determining goal for our citizens should be the idea of a civil society, but not as an end in itself for everyone, but as an instrument, as a means to realize their rights, freedoms and interests, to realize as a subject of social and legal relations in the state.

It is ineffective to delegate solving of all problems only to the authorities - this is a political axiom. It is utopian to believe that power can rule everything at once and simultaneously. The thesis "a strong state is a weak people" is bad. It is bad, including the fact that people in this case lack motives for growth. For example, the entrepreneur in this case is not looking for reserves of internal development, but for the official whom to give a bribe to. He will rather be engaged in liquid business, trade, financial fraud. Thus, the absence of civil society institutions forms a mobilization type of economics that does not have incentives for self-development, but moves only with the strong-willed impulses from above.

29 Марков С. А., Ярмак Ю. В. Вестник Российского философского общества. М.: СиДиПресс. 2007. Вып. № 1(41). С. 98-102. 
Civil society is a universal political stabilizer. When people can solve their problems through the structures of a civil society, and when there is no desire to act according to the methods of general destruction. Civil society is needed both as a civilian control of power, and as an institution for posing problems in front of the government. After all, a society is stable when the same person belongs to as many groups as possible - this is how he better understands the society as a whole.

At the same time, society should delegate to the government the right to set long-term goals, including the development of public relations through centralized efforts to improve the legal framework, organize the conditions and prerequisites for the emergence and functioning of various civil institutions, etc., herewith, monitoring strict compliance with the laws.

Therefore, the processes of democratization of the state power and the development of a civil society should take place as synchronously as possible. With such synchronism and unity, both vertical of the state power from above should contribute to this, and society itself from below. Under such conditions, Ukraine can reach the level of developed Western democracies due to the quality of a civil society functioning.

\section{SUMMARY}

The article presents an attempt to describe the socio-cultural aspect of the civil society transformation, to reveal the mechanisms of its emergence and formation through the activity component of human life, the legislative and legal framework functioning in the society. The analysis of self-organizing public formations as systemforming units of a civil society was carried out. The paper also offers a look at a civil society as a goal or a means of realizing the rights and freedoms of citizens of the modern Ukrainian society. The authors claim that civil society should become the decisive goal for citizens, but not as an end in itself for everyone, but as an instrument, 
as a means for the realization of their rights, freedoms and interests, the realization as a subject of social and legal relations in the state. It is argued that the processes of democratization of the state power and the development of a civil society should take place as synchronously as possible. With such synchronism and unity, both vertical of the state power from above should contribute to this, and society itself from below. Under such conditions, Ukraine can reach the level of developed Western democracies due to the quality of a civil society functioning.

\section{REFERENCES}

1. Дулин П. Г. Гражданское общество и государственная власть в Украине. Украина в системе современных ичивилизаций и трансформации государства и гражданского общества. - Одесса: «BMB», 2006. - C. 118-120.

2. Зеленко. Б. И. Гражданское общество. Глобалистика. Энияиклопедия. -М.: Радуга, 2003. - С. 276-279.

3. Каган М. С. Формирование личности как синергетический процесс. Синергетическая парадигма. - М.: Прогресс-Традиция, 2003. - C. 213-216.

4. Козинець О. Г. Історія становлення інституту прав людини в Англії. Наукові дослідження - теорія та експеримент '2006: матер. другої міжнар. наук.-практ. конф. - Полтава: «ІнтерГрафіка», 2006. T. 3. - C. 26-29.

5. Конев В. А. Каков наш путь к гражданскому обществу? Вестник Российского философского общества. - М.: СиДиПресс, 2006. Вып. № 2 (38). - С. 32-35.

6. Кравченко И. И. Государство и общество. Bonpocbl философии. 2007. Вып. № 7. - С. 19-35.

7. Марков С. А., Ярмак Ю. В. Вестник Российского философского общества. - М.: СиДиПресс. 2007. Вып. № 1 (41). C. 98-102. 
8. Мартишина Н. И. Взаимоконструирование реальности и человека Конструирование человека: сборник трудов Всероссийской научной конференции с международным участием: в 2 т. Т. 1. Ч. 1. - Томск: ТГПУ, 2008. - С. 210-215.

9. Мейс Джеймс. Спадщина голодомору: Україна як постгеноцидне суспільство: газета. «День». № 26. 2003. URL: http://www.day.kiev.ua/ru/arhiv/no207-2015

10. Неретина С. С. Памятка о гражданском обществе. Философские науки. - М.: Гуманитарий, 2008. № 7. - С. 23-38.

11. Одинцова О.Н. Проблема отчуждения и гражданское общество. Философия и будущее цุивилизации: тезисы докладов и выступлений IV Российского философского конгресса. Т. 4. - М.: Современные тетради, 2005. - С. 453.

12. Пасько Я. Феномен соціальної держави в історичній традиції Філософська думка. 2007. № 2. - С. 40-48.

13. Резник. Ю. М. Глобальное гражданское сообщество. Глобалистика. Эничиклопедия. - М.: Радуга, 2003. - С. 233.

14. Розин В. М. Особенности конструирования действительности и человека в философии и эзотерике. Конструирование человека: сборник трудов Всероссийской научной конференции с международным участием: в 2 т. Т. 1. Ч. 1. - Томск: ТГПУ, 2008. - С. 33-38.

15. Романенко С. С. Гуманизм как воплощение ценности человека. Наукові дослідження - теорія та експеримент '2006: матеріали другої міжнар. наук.-практ. конф. - Полтава: «ІнтерГрафіка», 2006. Т. 3. - С. 159-162.

16. Солонин Ю. Н. Практическая философия как предпосылка гражданского общества. Человек постсоветского пространства: сб. матер. конф. / под. ред В. В. Парцвания. Вып. № 3. - СПб.: Санкт-Петербургское философское общество, 2005. - C. 419-435. 
17. Сюндюков И. Джеймс Мейс - о скрытом «измерении» геноцида: газета. «День». № 207. 2015. URL: http://www.day.kiev.ua/ ru/arhiv/no207-2015

18. Фридмен, Милтон и Хайек, Фридрих. О свободе. Философия свободыл. Вып. 2. - М.: Социум, Три квадрата, 2003. $182 \mathrm{c}$.

19. Юдовская А. Я. Эволюция права в государствах Европы и Америки (XVII - XIX вв.). - СПб.: Спец. лит., 1996. - 164 с.

\section{Information about the author: Romanenko S. S.,}

Candidate of Philosophical Sciences, Associate Professor at the Department of Sport Games, State institution «South-Ukrainian National Pedagogical University named after K. D. Ushynsky» 26, Staroportofrankivska str., Odesa, 65020, Ukraine 